\title{
The Criminal Law Enforcement Policy in Online Prostitution Treatment
}

\section{Harjanto Mukti Eko Utomo ${ }^{*}$ and Umar Ma'ruf*)}

*) Student of Master of Law, Faculty of Law, Universitas Islam Sultan Agung (UNISSULA) and Regional Police of Central Java, email: mukti.41ah@gmail.com

**) Faculty of Law, Universitas Islam Sultan Agung

\begin{abstract}
.
The purpose of this research to find out and analyze criminal law enforcement policies in efforts to tackle online prostitution at the Central Java Regional Police Ditkrimsus, obstacles in criminal law enforcement policies in efforts to tackle online prostitution at the Ditkrimsus of Central Java Police and criminal law enforcement policies that should be implemented to tackle online prostitution in the Indonesian Police. The approach method used is juridical normative and juridical socio-logical method, the specifications in the research are descriptive analytical, population and sampling methods are all objects or all symptoms or all events or all units to be studied, data collection techniques use literature study and interviews, data analysis used is qualitative. Problems are analyzed using Progressive Law Theory, Law Enforcement Theory and Effectiveness Theory. Criminal law enforcement policies in efforts to tackle online prostitution at the Central Java Regional Police Ditkrimsus are in accordance with existing regulations. Obstacles in criminal law enforcement policies in efforts to tackle online prostitution at the Central Java Regional Police Ditkrimsus and solutions to overcome these obstacles. According to the author, do research by interviewing members of the Central Java Police that Barriers to law enforcement against online prostitution in the Central Java Regional Police are as follows: Community legal awareness is not optimal, there are limitations in facilities and infrastructure and very few cases have reached trial. Efforts made to overcome obstacles in law enforcement against online prostitution in the jurisdiction of the Central Java Regional Police include building partnerships with the wider community, improving facilities and facilities and for members should be given special training related to investigations into acts, online prostitution crime
\end{abstract}

Keywords: Policy; Criminal; Online; Prostitution.

\section{Introduction}

The use of internet media is increasingly complementing human needs for access to information and entertainment. The internet has enormous power to combine various characters of the mass media before. So the internet has become a medium that pampers human needs, easily, cheaply, quickly and efficiently. The development of communication media brought about new changes in the principles and ways of people using mass media or communication. The internet not only has a positive side, such as the existence of email, face book and others, but also has negative impacts including in the field of decency that has been rife recently, namely online prostitution. Prostitution is also evolving with the times, the era of Information and Communication Technology (ICT) also affect prostitution 
itself. $^{1}$

Prostitution in Indonesia it is considered a crime against morals or decency and prostitution is an activity that is illegal and against the law. Prostitution is a societal symptom in which women sell themselves for sexual acts as a livelihood. Prostitution is the surrender of women to many men with payments.

In English prostitution is called prostitution, which means it is not much different from the Latin language, namely prostitution, or immorality. People who commit prostitution are called prostitutes, also known as prostitutes or prostitutes. ${ }^{2}$

Prostitution in the Indonesian dictionary is explained as coming from the word "Prostitute" which means unfortunate, wretched, unlucky, failed, or badly sold. According to William Benton in Britannica Encyclopedia, prostitution is described as the practice of sexual intercourse that is carried out for a moment, which is more or less done with anyone for a reward in the form of money. Meanwhile, in terms of terms, prostitution or prostitution is the provision of sexual services performed by men or women to obtain money or satisfaction. ${ }^{3}$

According to Kartini Kartono in her book social pathology defines prostitution or prostitution as follows: 4

a. Prostitution is an event of self-sale with symptoms of the way of trading the body, honor and personality of many people to satisfy sexual desires in exchange for payment.

b. Prostitution is a form of sexual deviation with patterns of organization of sexual impulses / drives that are not natural and are not integrated in the form of the release of sexual desires without control with many people or promiscuity, accompanied by impersonal sexual exploitation without any effect of its nature.

c. Prostitution is the act of a woman or man by surrendering her body to commit sexual immorality for a fee.

On line is connected, connected, active and ready to operate, able to communicate with the computer. Online can also be interpreted as using the network, connected in a network between one device and other connected devices so that they can communicate with each other. The Internet is a collection of computer networks that connect academic, government, commercial, organizational and individual sites. The Internet provides access to telecommunications services and information resources for millions of uses throughout the world. ${ }^{5}$

This discussion regarding online prostitution discusses the practice of prostitution or prostitution using the internet or online media as a means of transaction for those prostitutes and those who want to use their services. Even

\footnotetext{
${ }^{1}$ Arif Zaenal Abidin, "Implementation of Online Prostitution Crime Investigation in Cirebon City Police Jurisdiction", in the Jurnal Daulat Hukum Volume 1 Issue 3 September 2018, p. 725, http://jurnal.unissula.ac.id/index.php/RH/ article / view / 3383

2 Kartini Kartono, 1997, Patologi Sosial, Jakarta : PT Raja Grafindo Persada, p. 177

3 Marwan Setiawan, 2015, Karakteristik Kriminalitas Anak dan Remaja, Ghalia Indonesia Publisher, p. 98

${ }^{4}$ Kartini Kartono, Patologi Sosial, Jakarta : Raja Grafindo Persada, 1997, p. 177

${ }^{5}$ http://www.penegrtianku.net/pengertian on-line
} 
though if we want to deepen the meaning, the meaning of online prostitution is prostitution transactions that use the internet as a means of connecting between Commercial Women and those who want to use their services. So the internet is only a means of support or connection.

If this prostitution is carried out in "Entangling Perpetrators of Prostitution Crime Online, then Article 27 paragraph (1) of Act No. 19 of 2016 concerning Electronic Information and Transactions can be applied, which reads: ${ }^{6}$

"Anyone who knowingly and without right distributes and / or transmits and / or causes access to electronic information and / or electronic documents that have contents violating decency will be punished with imprisonment of up to 6 (six) years and / or a maximum fine of Rp. . 1,000,000,000.00 ".

In addition to using Act No. 11 of 2008 concerning Electronic Information and Transactions which has been amended to Act No. 19 of 2016 concerning Electronic Information and Transactions, law enforcement against perpetrators of online prostitution crimes can be charged with the Criminal Code (KUHP). For the pimping process, it is contained in article 506 of the Criminal Code (KUHP), which is as follows: ${ }^{7}$

"Anyone who takes advantage of the sexual act of a woman and makes it a living, is punished by a maximum light imprisonment of 1 year." In addition to other articles, namely article 296 of the Criminal Code (KUHP).

The Law of the Republic of Indonesia No.44 of 2008 concerning Pornography also regulates the problem of prostitution. This law states it with the word pornographic services contained in article 1 paragraph (2) which contains: "Pornography services are all types of pornographic services provided by a natural person or corporation through live shows, cable television, terrestrial television, radio, telephone, internet and other electronic communications as well as newspapers, magazines and other printed material." 8

The practice of prostitution as regulated in this law is clarified in Article 4 paragraph (2) letter $d$ which contains prohibitions and restrictions. For commercial workers themselves, the pornography law mentions it in article 8. The crime of online prostitution that occurred in the jurisdiction of the Central Java Regional Police with Police Report Number: LP / A / 224 / VII / 2019 / Central Java, Ditreskrimsus, July 2, 2019. Letter Investigation Order No.Pol: SP.Sidik / 539 / VII / 2018 / Reskrimsus, July 2, 2019. Case: The criminal act of any person intentionally and without the right to distribute and / or transmit and / or make electronic information accessible and / or electronic documents that violate decency and / or everyone is prohibited from providing pornographic services that offer and advertise.

The formulation of the problem in this study are: What is the policy of criminal law enforcement in efforts to tackle online prostitution at the Central Java Regional Police's Ditkrimsus? Obstacles in criminal law enforcement policies in efforts to tackle online prostitution at the Ditkrimsus of Central Java Police? What

\footnotetext{
${ }^{6}$ Act No. 11 of 2008 concerning Electronic Information and Transactions

7 The Criminal Law code (KUHP)

${ }^{8}$ Act No.44 of 2008 on Pornography
} 
are the criminal law enforcement policies that should be implemented to tackle online prostitution in the Indonesian National Police?

\section{Research Methods}

The approach method uses juridical research in this research. It is intended that this research is viewed from the point of view of legal science and written regulations related to Criminal Law Enforcement Policies in Efforts to Overcome Online Prostitution in the Special Crime Directorate of the Central Java Regional Police. The specification in this study is an analytical description which aims to determine the Criminal Law Enforcement Policy in Efforts to Overcome Online Prostitution at the Special Crime Directorate of the Central Java Regional Police. The data collection method used is library research and field studies. The data obtained were collected and arranged systematically and then conducted a qualitative data analysis based on the discipline of law and assisted by other social sciences, which was then applied in the form of thesis writing

\section{Result and Discussion}

\subsection{Criminal Law Enforcement Policies In An Effort To Tackle Online Prostitution at the Central Java Regional Police's Ditkrimsus}

The birth of Act No. 11 of 2008 concerning Electronic Information and Transactions (ITE) is intended to provide many benefits, including ensuring legal certainty for people conducting electronic transactions, encouraging economic growth, preventing information technology-based crimes and protecting service users by utilizing information technology, but it turns out that the regulation regarding online prostitution has not been covered in the law, so that perpetrators of online prostitution practice are free to carry out their "business activities". Existing regulations such as the Criminal Code, Act No. 44 of 2008 concerning Pornography have not been able to solve these problems,

Laws regulating prostitution are the Criminal Code (KUHP), Act No. 11 of 2008 concerning Information and Electronic Transactions and Act No. 44 of 2008 concerning Pornography.

In law enforcement for cases of online prostitution in the jurisdiction of the Central Java Regional Police, it refers to Republic of Indonesia Act No. 11 of 2008 concerning Information and Electronic Transactions and or Article 30 of the Law of the Republic of Indonesia No. 44 of 2008 concerning Pornography.

\subsection{Obstacles in criminal law enforcement policies in efforts to tackle online prostitution at the Ditkrimsus of Central Java Police}

Barriers to law enforcement against online prostitution in the Central Java Regional Police are as follows:

a. Community legal awareness is not optimal

One of the obstacles in enforcing the law on criminal acts of prostitution online is the lack of legal awareness of the community which implies their 
disobedience to the law. According to Aipda Febriyanto ES, SH Banit Subdit V / Siber Ditreskrimsus Polda Central Java for several reasons, until now the legal awareness of the Indonesian people is still lacking, namely: Until now, the legal awareness of the Indonesian people in responding to cyber crime activities is still lacking. This is due, among others, to a lack of understanding and knowledge of the public regarding the types of cyber crime.

b. There are limitations in facilities and infrastructure

According to the interview the author conducted with Mr. Aipda Febriyanto ES, SH Banit, Subdit V / Siber, Ditreskrimsus Polda Central Java, he said that one of the obstacles in law enforcement in this online prostitution crime was the limited facilities and infrastructure owned by the Central Java Regional Police, because of the crime. done online then there are things that are technically only owned by the POLRI Headquarters.

c. Very few cases have reached trial

Cyber crime law enforcement, especially online prostitution crimes, still face obstacles so that very few crimes that have been investigated by the police have reached trial. This is due partly to insufficient evidence that is presented in each series of examinations.

Efforts made to overcome obstacles in law enforcement against online prostitution crimes in the jurisdiction of the Central Java Regional Police include the following:

a. Build partnerships with the community at large

Based on the result interview with Aipda Febriyanto ES, SH Banit Subdit V / Siber Ditreskrimsus Polda Central Java, efforts made by the jurisdiction of Polda Central Java, which in dealing with hambayan found in law enforcement against criminal acts of prostitution online, includes building partnerships in the wider community to help hack accounts related to the trafficking of women through online media.

b. Improve facilities and facilities

Another effort to overcome obstacles in law enforcement in the crime of prostitution carried out by the Central Java Police is to improve facilities and facilities.

Without certain facilities and facilities, it is impossible for law enforcement to proceed smoothly. These facilities and facilities, among others, cover educated and skilled human workers, good organization, adequate equipment, adequate finance and so on.

Criminal law enforcement policies that should be implemented to tackle online prostitution in the Indonesian National Police are non-penal (Preventive), Penal Effort (Repressive), formed a functional unit to trace cases of online prostitution on social media and the Police searched for prostitutes who were prostitutes and submitted them to social services.

\section{Closing}

In law enforcement for cases of online prostitution in the jurisdiction of the Central Java Regional Police, it refers to Republic of Indonesia Act No. 11 of 2008 concerning Information and Electronic Transactions which has been updated to 
Act No. 19 of 2016 concerning Information and Electronic Transactions and or Article 30 of Law of the Republic of Indonesia No. 44 of 2008 concerning Pornography. Obstacles in criminal law enforcement policies in efforts to tackle online prostitution at the Central Java Regional Police's Ditkrimsus namely: Community legal awareness is not optimal. There are limitations in facilities and infrastructure, Very few cases have reached the trial. Efforts made to overcome obstacles in law enforcement against online prostitution crimes in the jurisdiction of the Central Java Police include the following: Building partnerships with the community at large, Improving facilities and facilities. Criminal law enforcement policies that should be implemented to tackle online prostitution in the Indonesian National Police are non-penal (Preventive), Penal Effort (Repressive), formed a functional unit to trace cases of online prostitution on social media and the Police searched for prostitutes who were prostitutes and submitted them to social services.

Criminal law enforcement policies in the effort to tackle online prostitution at Ditkrimsus Polda must strictly comply with applicable and strict rules in imposing crimes so that it is hoped that there will be a deterrent effect for prostitutes, pimps and mashed men. The police, especially the Central Java Regional Police, must improve facilities and infrastructure in exposing criminal acts of prostitution online. In the reform of criminal law for all circles in online prostitution must be ensnared with regulations so that there is a deterrent effect for all

\section{Bibliography}

Arif Zaenal Abidin, "Implementation of Online Prostitution Crime Investigation in Cirebon City Police Jurisdiction", in Jurnal Daulat Hukum Volume 1 Issue September 3 2018, retrieved from: http://jurnal.unissula.ac.id/index.php/RH/article/view/3383

http://www.penegrtianku.net/ understanding on line

Abdul Halik, 2013, Komunikasi Massa, Makasar: Alauddin University Press

Abdul Wahid, 2010, Tindak Pidana Mayantara, Bandung: Refika Aditama

Kartini Kartono, 1997, Patologi Sosial, Jakarta: PT Raja Grafindo Persada

Marwan Setiawan, 2015, Karakteristik Kriminalitas Anak dan Remaja, (Bogor: Ghalia Indonesia Publisher

Sidqi Ferin Diana, 2017, Kebijakan Hukum Pidana Dalam Pemberantasan Kejahatan Perdagangan Orang (Trafficing), Semarang: Jurnal Khaira Ummah

Arya Mahardika Pradana, 2015, Tinjauan Hukum Pidana Terhadap Prostitusi Dan Pertanggungjawaban Pidana Para PIhak Yang Terlibat Dalam Prostitusi, Jurnal Pembaharuan Hukum

Act No. 11 of 2008 concerning Electronic Information and Transactions

Criminal Code (KUHP)

Act No.44 of 2008 on Pornography 